\title{
POLITICAL PRISONERS AND OPPRESSED PERSONS CLASS AND THE SOVIET UNION
}

\section{David Matas}

The self exiled class hasended. And it is high time it did. While it lasted, it was a form of favouritism to refugee claimants from Eastern Europe. Refugee claimants from Eastern Europe did not have to prove they were refugees. They were presumed to be refugees. As long as they were outside of Canada, outside of Eastern Europe, and sponsored by either the Canadian government or Canadian private sponsors, they could come to Canada as landed immigrants. Claimants from Indochina had the same favoured treatment.

But for everyoneelse, if they wanted to come to Canada as refugees, they had to prove they were refugees. Everyone else had to prove he/she had a well founded fear of persecution. And, in many cases, even where there were substantial grounds for thinking that there would be persecution, proof was not that easy.

Even at the height of the Cold War, the self exiled class did not seem all that fair. It was not as if Eastern Europeans were the peoples, from the advent of the class in 1974, to its ending in 1990, that were the worst persecuted. El Salvadoreans, Guatemalans, Argentineans, Lebanese, Sri Lankans, Haitians have suffered horrors that made the problems of Eastern Europe pale by comparison. If Canada were to presume people from certain countries to be refugees, a far better choice could have been made than the citizens of Eastern Europe.

The professed aim of the self exiled class was to protect against exit controls. Exit controls, which all Eastern European countries imposed, meant that a person who stayed outside his/her country longer than permitted was subject to punishment on return. Exit controls also meant that emigration was impossible from within Eastern Europe. The self exiled class served a dual purpose protecting people against persecution from violation of exit controls, and allowing for immigration to Canada for Eastern Europeans once they had left Eastern Europe, because immigration while they still were within Eastern Europe was impossible.

There was a logic to the class, but it was not a logic that was consistently applied. China, North Korea, Mongolia all had exit controls as severe as those in Communist Indochina or Eastern Europe. But none of those countries was ever in a designated class. Citizens of those countries have never been presumed to be refugees. Claimants from the countries had to establish they met the refugee definition.

Although the self exiled class was

$$
\begin{aligned}
& \text { Even while the Cold War } \\
& \text { was in full force, the logic } \\
& \text { for the self exiled class was } \\
& \text { not completely } \\
& \text { convincing. Once the } \\
& \text { Cold War ended the logic } \\
& \text { for the class disappeared. } \\
& \text { Yet the class carried on. }
\end{aligned}
$$

legislated by cabinet under the authority to protect the displaced and the persecuted, the motivation was not strictly humanitarian. The motivation was a mixture of politics, economics and humanity.

A refugee is someone who has a well founded fear of persecution. A person found to be a refugee is a person whom his/her government cannot or will not protect. A finding that a person is a refugee is a finding that his/her government is a persecutor.

A presumption that a person is a refugee, which is made with the self exiled class, is a presumption that the government of the country the claimant has fled is a persecutor. The self exiled class presumed, without proof in individual cases, that Eastern European government persecuted their citizens.

It is no coincidence that all the countries in the self exiled class and the Indochinese designated class were countries with Communist governments. The very existence of the self exiled class was a political statement of anti-Communism. It was a statement that Communism is persecution. No proof was necessary. That statement was not strictly humanitarian. It was also political.

Canada, through its history, has been a country of immigration. Canada sought immigrants, initially, to settle the country. Now it needs immigrants simply in order to sustain its economy.

When Canada admitted refugees from Eastern Europe through the self exiled class, the refugees did not come just for temporary protection from persecution. They came as immigrants. Their admission was not just part of refugee policy. It was part of overall immigration policy.

Refugee policy, generally, in the Government of Canada suffers from its coming out of the Immigration Department. No element of refugee admission is examined solely from the angle of protection. Because it is the immigration Department that decides on refugee admission, immigration and refugee policy become inextricably intertwined.

The self exiled class became a handy way to get immigrants from Eastern Europe, when no other obvious route was available. What, in reality, were immigrants from Eastern Europe, were forced into a refugee pigeonhole where many of them did not belong. For the government what was important was that these people be admitted to Canada, rather than the category into which they fell. The presumed refugee category, the 
self exiled class, served the purpose of being a vehicle for immigration. So it was used.

Of course, the trouble with presuming Communists in Eastern Europe to be persecutors, the trouble with taking immigrants from Eastern Europe and calling them refugees, when many were not, was that the system was unfair to claimants elsewhere. Claimants not so favoured mights well have had a great deal more grounds for fearing persecution than claimants from Eastern Europe. But many such claimants could not enter as refugees, whereas Eastern Europeans could.

Even while the Cold War was in full force, the logic for the self exiled class was not completely convincing. Once the Cold War ended the logic for the class disappeared. Yet the class carried on. It ended on August 31 of 1990.

If the self exiled class was unfair to non Eastern European refugee claimants before the ending of the Cold War, that unfairness became glaring once the Cold War had ended. Refugee sponsorship in Canada is both private and public. Private sponsorship is unlimited. The ceiling is as high as private sponsors want to go.

Public sponsorship, on the other hand, is strictly limited. For 1990, the ceiling was set at 13,000 . 3,500 of these 13,000 places were allocated to Eastern Europeans. From 1989 to 1990 the slots allocated to Eastern Europe actually went up, from 3,400 to 3,500 . The overall total from 1989 to 1990 remained the same, at 13,000 .

So, Canada saw the perverse result of increasing its government sponsorship of presumed refugees from Eastern Europe, as the Cold War ended, and decreasing, correspondingly, its governmentsponsorship of real refugees who met the refugee definition. Before the self exiled class ended, on August 31, 1990 , it was not phased out. Instead, the programme was accelerated.

The continuation of the self exiled class beyond its real need had an impact on private sponsored refugees as well, because of the programme of travel loans. The Government of Canada offers travel loans to refugees resettling in Canada from abroad. The expenditure is a loan, not a gift. The experience of the Government of Canada is that the loans are invariably repaid, once the refugees come to Canada and start working. Without them, the refugees or their sponsors would be hard pressed to come up with the cash to bring the refugees to Canada.

Recently the statutory ceiling was reached for the total amount of these travel loans. So the loans stopped. Legislation went through Parliament

For all the miseries that the USSR has suffered under Stalin and Brezhnev, no one

blames themselves. Everyone blames

another ethnic group. The Azeris blame

the Armenians. The Kirghiz blame the

Uzbeks. The Macedonian Turks blame the

Georgians. The Ukrainians blame the

Russians. And everyone blames the Jews.

being used for real refugees elsewhere in the world.

Compounding the problem was the priority the government gave to travel loans for government sponsored refugees. Even after travel loansstopped for private sponsored refugees, loans continued for government sponsored refugees, including government sponsored refugees in the self exiled class. Travel loans ceased to be available for real refugees, sponsored by the private sector. They continued to be available to refugees in name only coming from Eastern Europe sponsored by the government.

Travel loans are more than just a government programme. They are a contractual arrangement with the sponsors. Sponsors of real refugees who do not come from Eastern Europe have seen the Government violate its contractual promise to provide loans because Eastern European self exiled immigrants have taken the total travel loan amount up to the ceiling.

this past spring to raise the ceiling. But, even though the legislation has passed, the loans have still not started up again. The legal limit may have been lifted. But the Government does not have the cash to float the loans.

And one significant reason why the loans have dried up is the self exiled class. I mentioned before that private sponsorship was unlimited. For months the self exiled class continued to operate in Eastern Europe even after exit controls had gone.

The continuation of the self exiled class in Canada and the lifting of exit controls in Eastern Europe allowed for the operation of an immigration scam. Would be immigrants from Eastern Europe who could not qualify under any other immigration program simply parked themselves outside of Eastern Europe, awaited private sponsorship, and then arrived.

These people wereeligible for travel loans. And their using the time loans dried up the pool that was available and
The self exiled class, which kept running when the need for it had gone, created yet another problem for refugees generally, a delay in the granting of visas. The Government of Canada decided to delay granting visas for August and September, because its visa numbers had been rising ahead of the numbers targeted for the year. To keep the annual figures at targeted levels the government decided to withhold visas for August and September from all those who qualified in these two months for visas.

This visa withholding does not apply to government sponsored refugees. It does apply to private sponsored refugees, as well as to non refugee immigrants.

To my mind, the main culprit in the visa withholding is the policy of visa delay itself. It is an unnecessary hardship to delay resettlement of refugees or reunion of families for two months once they already qualify to enter. Nonetheless, if we accept this visa delay policy as given, then one element that 
caused its introduction was the self exiled class. A self exiled class run wild once exit controls had disappeared from Eastern Europe helped to create a build up of numbers overall larger than anticipated for the granting of visas. The self exiled class helped to generate the visa delay policy.

So the ending of the self exiled class is welcome. But, I believe the Government has gone too far. It has gone from one extreme to another. Before it treated Eastern Europeans as if everyone was a presumed refugee. Now it treats every Eastern European as if he/she were in the same situation as everyone claiming refugee status anywhere else in the world.

However, there is unique situation that the Government policy makers have overlooked, the situation in the Soviet Union. TheSoviet Union is in the process of disintegrating through ethnic violence in the republics. Communism repressed national ethnic conflicts, but did not resolve them. Now that the Communist lid had come off, these conflicts have returned, with even greater force than they had before.

For all the miseries that the USSR has suffered under Stalin and Brezhnev, no one blames themselves. Everyone blames another ethnic group. The Azeris blame the Armenians. The Kirghiz blame the Uzbeks. The Macedonian Turks blame the Georgians. The Ukrainians blame the Russians. And everyone blames the Jews.

Inter ethnic violence in the Soviet Union is everywhere. The Soviet authorities oscillate between doing nothing and overreacting in a return to bloody repression.

A huge internal refugee population has been created. When I was in the Soviet Union in June, 1990, there was an estimated 700,000 of these internal refugees, fleeing danger in their home republics and seeking protection in another.

The Soviet Union is ill equipped to deal with this internal refugee population. Restrictions on internal freedom of movement mean that refugees cannot work, cannot get residences, cannot send their children to school in the new locations to which they have fled. Refugees are living on the streets in Moscow, on the floors of buildings without bedding.

These people need the benefit of resettlement outside the Soviet Union. But it is virtually impossible for them to get it. To be within the refugee definition a person must be outside the country of his/her nationality. A person who has not fled is outside the protection of Refugee Convention, outside the mandate of the United Nations High Commission for Refugees.

If these international refugees could leave the Soviet Union, they could qualify as refugees. The UNHCR Handbook on Procedures and Criteria for Determining Refugee Status says:

"The fear of being persecuted need not always extend to the whole territory of the refugee's country of
The Political Prisoners and Oppressed Persons Class was not introduced to deal with a country like the Soviet Union - a vast country with an internal refugee population.

nationality. Thus in ethnic clashes or in cases of grave disturbances involving civil war conditions, persecution of a specific ethnic or national group may occur in only one part of the country.

In such situations, a person will not be excluded from refugee status merely because he could have sought refuge in another part of the same country, if under all the circumstances it would not have been reasonable to expect him to do so."

The trouble is that these people cannot leave. As exit controls in Eastern Europe have disappeared, entry controls have arisen. It is no longer possible for Eastern Europeans to go to Italy or Austria the way they used to go to wait for resettlement in Canada or other countries. Italians and Austrians, Europeans generally, are no longer letting such people in. Now that Eastern Europeans can leave, the acquiring of visas from the West becomes more and more difficult.

Israel has become a country of asylum to Soviet Jewish internal refugees. But the desire to flee far exceeds the Israeli generous response. Israel will receive 100,000 Jewish refugees this year from the Soviet Union. But the requests to flee to Israel that have come from within the Jewish community of the Soviet Union are now over one million.

The United States has shut off one avenue of entry from the Soviet Union, but opened up another. The U.S., like Canada, used to allow admission to the U.S. for Soviets as refugees when an application was made in a third country. The U.S. has closed third country processing down and shifted it, instead, to Moscow.

For 1990, the U.S. has said it would admit 50,000 refugees directly from within the Soviet Union. It has categorized four categories of Soviets as presumptive refugees - Jews, Evangelicals, Ukrainian Orthodox Christians and Ukrainian Catholics. These presumptive refugees do not have to meet the full rigours of the refugee definition, but instead only a modified form of it. They have to show they have a credible basis for a refugee claim.

This credible basis test is a test that is familiar to Canadians. It is the test that is used inland in Canada for screening out manifestly unfounded claims. For the inland claims procedure in Canada a person who passes credible basis goes on to a full hearing about whether or nothe/ she is a refugee. A person who fails credible basis is subject to removal 72 hours after the removal order is made.

There is something else in the American procedure that should also be familiar to Canadians - the guidelines for the refugee definition and credibility assessment. I was part of a Government of Canada task force in 1981 that drafted guidelines on the refugee definition and credibility assessment. The Americans have adopted these guidelines word for word in their entirety and incorporated them in instructions, not just to the Soviet 
Union but to all U.S. overseas visa offices processing refugee claims.

Canada, to my knowledge, has done no such thing. I cannot help but wonder why Canadian drafted guidelines should be good enough for the Americans, but not good enough for the Government of Canada.

The U.S. system is, in some ways, more generous, and in other ways, less generous that the Canadian system for Soviet refugees. Canada still allows Soviet refugee admission from third countries, if the Soviet refugees can get to a third country to make their claims. The U.S. does not. Canada does not, however, allow direct refugee admission from within the Soviet Union as the U.S. does.

The notion of direct refugee admission from the country of origin, though not part of the U.N. Refugee Convention,is part of Canadian law in another context. One of the Canadian designated classes, designated to protect the displaced and persecuted, is PPOP the Political Prisoners and Oppressed Persons Class.

The Political Prisoners and Oppressed Persons Class includes people who otherwise meet the refugee definition except for the fact that they remain in their country of citizenship. Currently there are three countries in the class - Guatemala, El Salvador and Chile.

The Political Prisoners and Oppressed Persons Class was not introduced to deal with a country like the Soviet Union - a vast country with an internal refugee population. Instead the class had an altogether different objective in mind. Its objective was to justify visa imposition.

As repression flourished in Latin America in the seventies and eighties, Canada received, spontaneously, a large number of refugee claimants, from countries for which Canada had imposed no visa requirement. Once a visa requirement is imposed a person will not be allowed on an airplane to come to Canada without a visa. Without a visa requirement, a person can come to Canada with only a passport, and, on arrival, claim refugee status. These spontaneous arrivals from Latin

America came in significant enough numbers to worry immigration officials.

So, the Government of Canada imposed visa requirements on the countries to cut off the flow of spontaneous arrivals. However, simply imposing a visa requirement and doing nothing more would have prevented real refugees from escaping the worst forms of persecution. The Government, at the time it imposed a visa requirement on a country, inserted the country into the Political Prisoners and Oppressed

\section{The refugee problems of Eastern Europe have not ended with the end of the Cold War. There remains a substantial refugee population in the Soviet Union that needs both protection and resettlement.}

Persons Class or its predecessor the Latin American designated class. The idea was that these refugees would have a safety valve. They could not come to Canada to claim protection, but they could claim protection at the Canadian visa office in their home country. If it was granted, then they could come.

There has been a long standing debate between the non governmental community and the government about this trade off between visa imposition and home country refugee processing. The feeling of the non governmental community is that home country refuge processing does not offer the protection that refugee processing in Canada would do.

Claimants remain in danger while the claim is being processed. Due process procedural protections are nowhere near as high at Canadian visa offices abroad as for the inland claims systems. Evidence of sequelae of torture is harder to get from doctors in the home country, who themselves fear persecution if they assist in refugee claims, than in Canada. There are many considerations in this debate. I have just mentioned a few. The whole debate is set out in "Closing the Doors; The Failure of Refugee Protection", a book I have written with Ilana Simon.

The point I would make here is this debate is not relevant to refugee claims made within the Soviet Union. El Salvador and Guatemala are small countries. Chile, though larger, is concentrated in Santiago. Persecution in these countries has come from government oppression, not from ethnic conflict. A person in danger in one place in each of these countries is in danger everywhere within the country.

Armenians, however, in Moscow claiming refugee status from the Canadian embassy there, if they could, are not in the same danger from Azeris as they would be if the claims were made in Azerbaijan. It is not reasonable to expect Armenians to resettle in Moscow. It is reasonable to allow them to apply for Canadian protection from Moscow. PPOP does not make much sense for Latin America. But is makes a lot of sense for the Soviet Union.

I propose that the Soviet Union be designated as a country coming within the PPOP list. That would give us a system somewhat like the Americans to allow for Soviet refugee admission from within the Soviet Union. It would be responsive to the international refugee problem the Soviet Union faces. And it would be, to use the terms of the Canadian Immigration Act, in accordance with Canada's Humanitarian tradition with respect to the displaced and the persecuted.

The refugee problems of Eastern Europe have not ended with the end of the Cold War. There remains a substantial refugee population in the Soviet Union that needs both protection and resettlement. The end of the self exiled class has turned a blind eye to this problem. Putting the Soviet Union in PPOP would help to address the needs of these internal Soviet refugees. $\mathbf{R}$

(Daroid Matas is chair of the working group on Ooerseas Protection of the Canadian Council for Refugees.) 